\title{
Mesophilic anaerobic digestion of damask rose bagasse with different proportions of cattle manure
}

\author{
A.R. Doaguie ${ }^{1}$, A. Ghazanfari ${ }^{2}$, L.G. Tabil ${ }^{3 *}$ \\ ${ }^{I}$ M.S. Student, Department of Mechanic of Agricultural Machineries, Shahid Bahonar University, Kerman, Iran. \\ ${ }^{2}$ Professor, Department of Mechanic of Agricultural Machineries, Shahid Bahonar University, Kerman, Iran. \\ ${ }^{3}$ Professor, Department of Chemical \& Biological Engineering, University of Saskatchewan, Saskatoon, SK Canada. \\ *Email: lope.tabil@usask.ca
}

Doaguie, A.R., A. Ghazanfari and L.G. Tabil. 2012. Mesophilic anaerobic digestion of damask rose bagasse with different proportions of cattle manure. Canadian Biosystems Engineering/Le génie des biosystèmes au Canada 54:8.1-8.6. The flowers of damask rose plants (Rosa damascena Mill.) are utilized in hydro-distillation industries to produce concentrated rose water and essential oils. Rose bagasse is the main byproduct of these industries that are conventionally used as compost. The objective of this research was to investigate the potential and the kinetics of biogas production from this bagasse mixed with cattle manure with mass proportions of $95,90,85$ and $80 \%$. The anaerobic digestion process was carried out at two temperatures of 35 and $45^{\circ} \mathrm{C}$ for 30 days of hydraulic retention time. The daily $\mathrm{pH}$, biogas production and generated methane were measured. The results indicated that biogas production rate increased with increase in the proportion of cow manure and temperature. Maximum cumulative biogas yield was 0.427 and $0.369 \mathrm{~m}^{3} / \mathrm{kg}$ of volatile solids in $45^{\circ} \mathrm{C}$ and $35^{\circ} \mathrm{C}$, respectively. The volatile solids reductions in the various treatments ranged from 64.9 to $81.4 \%$. The cumulative daily biogas yield for the treatments were modeled using a modified form of Gompertz equation with resulting $\mathrm{R}^{2}$ values greater than 0.94 . Keywords: biogas, damask rose bagasse, cattle manure, modeling, temperature.

Les fleurs des rosiers damask (Rosa damascena Mill.) sont utilisées dans l'industrie d'hydrodistillation pour produire une eau de rose concentrée et des huiles essentielles. Le sous produit de cette industrie, la bagasse de rosiers, est habituellement utilisée comme compost. L'objectif de ce projet de recherche était d'évaluer le potentiel et les mécanismes liés à la production de biogaz à partir d'un mélange de bagasse et de fumier de bovins dans des proportions massiques de $95,90,85$ et $80 \%$. Le processus de digestion anaérobique était réalisée à deux températures, 35 et $45^{\circ} \mathrm{C}$, et pour une période de rétention de 30 jours. Le $\mathrm{pH}$, la production de biogaz et le méthane généré étaient mesurés quotidiennement. Les résultats indiquaient que le taux de production de biogaz augmentait avec des augmentations de la proportion de fumier de bovin et de la température. La production cumulative maximale du biogaz était de 0,427 et $0,369 \mathrm{~m}^{3} / \mathrm{kg}$ de solides volatiles à des températures de $45^{\circ} \mathrm{C}$ et $35^{\circ} \mathrm{C}$, respectivement. Les réductions de solides volatiles pour les différents traitements variaient entre 64,9 et $81,4 \%$. La production cumulative quotidienne de biogaz pour les traitements a été prédite en utilisant une forme modifiée de l'équation Gompertz et résultant en des valeurs de $\mathrm{R}^{2}$ supérieures à 0,94 . Mots clés: biogaz, bagasse de rosiers damask, fumier de bovins, modélisation, température.

\section{INTRODUCTION}

Damask rose plants (Rosa damascena Mill.) are grown in many semi-arid regions of the world (Koppar and Pullammanappallil 2008). Bulgaria, France, Turkey, Romania, Morocco, China, and Iran are the major producers of damask rose. It is estimated that Iran annually produces close to 10,000 metric tonnes of damask rose flowers (Doaguei, 2009). A major portion of these flowers are used in hydro-distillation plants for production of concentrated rose water and essential oils. The concentrated essential oils and rose water are exported to some European countries where they are further processed for perfume production (Jalali-Heravi et al. 2008). Damask rose bagasse (DRB) is a byproduct of the hydro-distillation process of damask rose flower. Conventionally, rose bagasse is used for composting; however, as other agricultural wastes, this bagasse can be used for biogas production by anaerobic digestion.

In anaerobic digestion, various bacteria digest slurry of agricultural wastes or residues and biogas is generated. The amount of biogas yield and the rate of biomass degradation are related to the $\mathrm{pH}$ and temperature of the digesting medium, duration of the digestion, the ingredients, and the proportion of the utilized materials. Anaerobic digestion is typically carried out either in the mesophilic $\left(30-50^{\circ} \mathrm{C}\right)$ or thermophilic $\left(50-60^{\circ} \mathrm{C}\right)$ temperature range. The latter offers a greater potential for destroying weed seeds and pathogens, as the residues of anaerobic digestion are returned to soils in form of organic soil additives (Koppar and Pullammanappallil 2008). However, the thermophilic process in most cases requires an external source of heating (Chae et al. 2008).

In anaerobic digestion, the rate of gas production is directly related to the temperature of the medium (Hansen et al. 1998). Higher temperatures reduce the required time for methane generation but the ultimate methane yield, in mesophilic condition, is independent of temperature (Hashimoto et al. 1981). In general, in a higher temperature medium, the rate of biomass degradation increases but at the same time, more ammonia $\left(\mathrm{NH}_{3}\right)$ is generated which causes a decrease in overall biogas production (Hansen et al. 1999; Angelidaki and Ahring 1994). 
The $\mathrm{pH}$ of the medium is another important parameter affecting the growth of bacteria during anaerobic digestion. A pH range of 6.7 -7.4 is suitable for most methanogenic bacteria to function (Yadvika et al. 2004; Hansen et al. 1999; Gomec and Speece 2003). Jain and Mattiasson (1998) indicated that around this range of $\mathrm{pH}$, the efficiency of methane production was at its optimum level. Lay et al. (1997) studied the influences of $\mathrm{pH}$ on methane production from digestion of sludge. They indicated that the optimum $\mathrm{pH}$ range was in the range of 6.6 to 7.8 .

The biomass used in an anaerobic digestion process is often a mixture of different biomaterials which are gradually digested by bacteria. The rate of biogas production from digestion of organic wastes depends on the relative proportion of the components of the digesting materials and the number of existing bacteria in the slurry (Dellepiane et al. 2003; Zandersons et al. 1999). Research has proven that co-digestion of biomass with some percentage of livestock manure, i.e. cattle manure can increase methane yield by increasing bacterial diversities and reducing inhibition of methanogenesis (Macias-Corral et al. 2008; Rajasekaran et al. 1989). For faster bacterial growth and enhancing biogas production, a starting inoculum is usually added to the slurry. Well-digested slurry from domestic animal manure is often used as the starting inoculum (El Shinnawi et al. 1989; Somayaji and Khanna 1994).

Anaerobic digestion of agricultural wastes is a relatively slow process. The holding time of the digesting material in a slurry medium for biogas production is referred to as the hydraulic retention time (HRT). The effective HRT is generally decreased with an increasing temperature of the slurry. For an optimum biogas yield, depending on the type of biomass and digestion temperature, a HRT of 30 to 50 days has been suggested (Yadvika et al. 2004; Zennaki et al. 1996; Garba 1996).

The DRB produced in the hydro-distillation industries has the potential to be used for biogas production. This study was conducted to assess the potential of biogas production from DRB and to investigate the effects of: (a) various combinations of DRB and cattle manure (CM); (b) temperature; and (c) hydraulic retention time on the rate of production and total yield of biogas.

\section{MATERIALS AND METHODS}

\section{Experimental procedures}

The required DRB for the experiments was supplied by a local hydro-distillation plant, near Kerman, Iran. The original moisture content of this bagasse was $81.4 \%$ wet basis (wb). Cattle manure was collected from a cattle farm, where hay and straw constituted the main feeding ingredients. Table 1 lists some characteristics of damask rose bagasse and cattle manure used for anaerobic digestion.

Table 1. Characterization of damask rose bagasse (DRB) and cattle manure (CM).

\begin{tabular}{|c|c|c|}
\hline Analysis & DRB & $\mathrm{CM}$ \\
\hline Total solid $\left(\%, w^{*}\right)$ & 18.6 & 24.1 \\
\hline Volatile solid $\left(\%\right.$ of $\left.\mathrm{TS}^{* *}\right)$ & 94.4 & 75.0 \\
\hline Volatile solid $(\%, \mathrm{ww})$ & 17.6 & 18.1 \\
\hline Packing density $\left(\mathrm{kg} / \mathrm{m}^{3}\right)$ & 1015.4 & 570.9 \\
\hline Moisture $(\%, w b)$ & 81.4 & 75.9 \\
\hline $\mathrm{pH}$ & 4.8 & 8.8 \\
\hline
\end{tabular}

"ww: wet weight, ${ }^{* *}$ TS: Total solids

The reactors used for the experiments consisted of cylindrical polyethylene jars with inner diameter and height of $250.0 \mathrm{~mm}$ and $300.0 \mathrm{~mm}$, respectively. Each reactor was sealed with a top lid equipped with a plastic O-ring to prevent any gas leakage. Two ports were mounted on the reactors, one at the top for gas outlet, and the other at the bottom for sample withdrawal.

The experimental temperatures were investigated at two levels of $35^{\circ} \mathrm{C}$ and $45^{\circ} \mathrm{C}$ and the ratio of DRB to $\mathrm{CM}$ had four mass percentage levels of: 80.0/20.0, 85.0/15.0, 90.0:10.0, and 95.0/5.0. The designation, the physical process variables, and the composition proportion for each treatment are given in Table 2. Prior to the experiments, active slurry was prepared by mixing $1.0 \mathrm{~kg}$ of CM and 1.0 $\mathrm{L}$ of distilled water in a reactor. This mixture was kept at $35^{\circ} \mathrm{C}$ for 60 days, to ensure the maximum bacteria growth and complete digestion of the nutrients. During this period, the mixture was periodically shaken and the generated biogas was allowed to exit through the gas outlet.

To conduct the experiments, each reactor was initially loaded with $450 \mathrm{~g}$ mixture of DRB and CM. Then, 500.0 $\mathrm{mL}$ distilled water and $50.0 \mathrm{~g}$ of active slurry, as the initial inoculum, were added to each reactor. In addition, 10.0

Table 2. The average composition of the treatments digested at $35^{\circ} \mathrm{C}$ and $45^{\circ} \mathrm{C}$.

\begin{tabular}{|c|c|c|c|c|c|c|c|}
\hline $\begin{array}{c}\text { Treatment } \\
\text { Designations }\end{array}$ & $\begin{array}{l}\mathrm{DRB} / \mathrm{CM} \\
(\% \mathrm{v} / \% \mathrm{v})\end{array}$ & $\begin{array}{c}\text { DRB } \\
(\%, w w)\end{array}$ & $\begin{array}{c}\text { CM } \\
(\%, w w)\end{array}$ & $\begin{array}{l}\text { Inoculum } \\
(\%, w w)\end{array}$ & $\begin{array}{l}\text { Dilution } \\
(\%, w w)\end{array}$ & $\begin{array}{c}\text { TS } \\
(\%, w w)^{*}\end{array}$ & $\begin{array}{c}\text { VS } \\
(\% \text { of TS })^{*}\end{array}$ \\
\hline $80 / 20$ & $80.0 / 20.0$ & 36.0 & 9.0 & 5.0 & 50.0 & 19.7 & 90.5 \\
\hline $85 / 15$ & $85.0 / 15.0$ & 38.3 & 6.7 & 5.0 & 50.0 & 19.4 & 91.5 \\
\hline $90 / 10$ & $90.0 / 10.0$ & 40.5 & 4.5 & 5.0 & 50.0 & 19.1 & 92.5 \\
\hline $95 / 5$ & $95.0 / 5.0$ & 42.7 & 2.3 & 5.0 & 50.0 & 18.9 & 93.4 \\
\hline
\end{tabular}

*Average of values are shown, $\mathrm{n}=3$.

DRB: Damask rose bagasse, CM: cattle manure, TS: total solids, VS: volatile solids. 
$\mathrm{g} \cdot \mathrm{L}^{-1}$ of sodium bicarbonate was also added to buffer against $\mathrm{pH}$ changes. The digesters were placed in two water baths with temperatures of $35^{\circ} \mathrm{C}$ and $45^{\circ} \mathrm{C}$ and the slurries in the digesters were periodically stirred by shaking the individual reactors. The HRT of all treatments was 30 days.

\section{Analytical measurements}

During the experiments, the $\mathrm{pH}$ of the slurry was periodically measured to ensure the $\mathrm{pH}$ was maintained within the range of $6.7-7.4$. The daily biogas produced by the individual digesters was measured using a liquid displacement column. Every five days, the generated biogas was passed through a jar containing $3 \%(\mathrm{v} / \mathrm{v}) \mathrm{NaOH}$ solution and its methane content was measured by liquid displacement method. The total solids (TS), volatile solids (VS), and moisture of the feed and samples were all analyzed using standard methods (APHA 1998). Total solids of the samples were determined gravimetrically by drying them at $105^{\circ} \mathrm{C}$ for $24 \mathrm{~h}$. Volatile solids content was determined by igniting the residues of the TS in a muffle furnace at $550^{\circ} \mathrm{C}$ for $2 \mathrm{~h}$ and determining the ash-free dry mass after cooling and desiccating.

\section{Statistical analyses and modeling}

Experiments were performed for determining the effects of temperature, percentage of $\mathrm{CM}$, and their interaction on effective digestion and maximum biogas yield in batch conditions. A $2 \times 4$ factorial design was used to investigate the effect of temperature (two levels) and the ratio of DRB to $\mathrm{CM}$ (four levels) and their interactions on biogas production. All the experiments were conducted in three replicates. The collected data were subjected to analysis of variance (ANOVA) as 2-way factorial design, using the SPSS statistical software (SPSS version 17.0, SPSS Inc., 2009). The significant differences between treatment means were further evaluated using LSD range test.

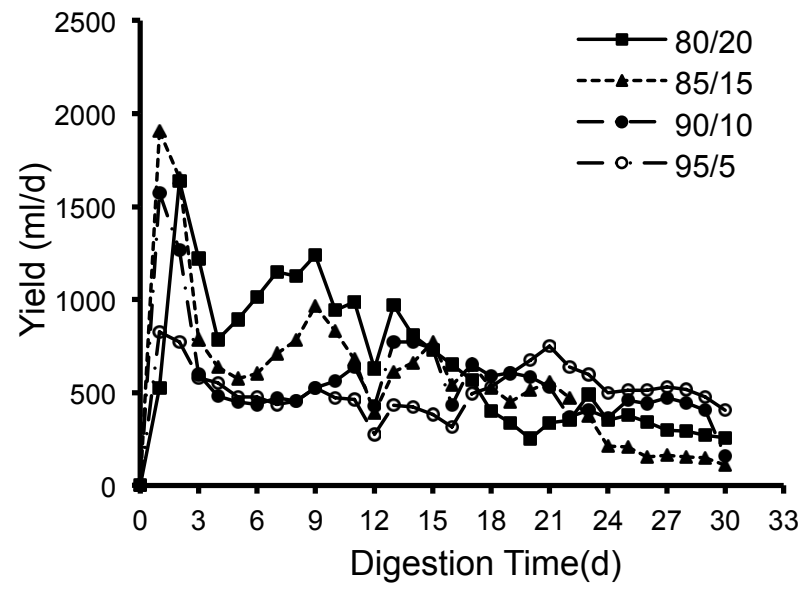

Fig. 1. Daily biogas production for treatments performed at $35^{\circ} \mathrm{C}$.
Daily cumulative biogas yield was modeled using a modified form of Gompertz growth model. This model assumes that daily cumulative biogas production $\mathrm{M}$ $\left(\mathrm{m}^{3} / \mathrm{kgVS}\right)$ is a function of digestion time $\mathrm{t}$ (day) described by the following equation:

$$
M(t)=P \exp \left\{-\exp \left[\frac{R_{m} \cdot e}{P}(\gamma-t)+1\right]\right\}
$$

where $\mathrm{P}$ is biogas yield potential $\left(\mathrm{m}^{3} / \mathrm{kgVS}\right), \mathrm{R}_{\mathrm{m}}$ is the maximum biogas production rate $\left(\mathrm{m}^{3} / \mathrm{kgVS}\right.$.d), and $\gamma$ is the yield lag time in day (Mu et al. 2006; Koppar and Pullammanappallil 2008). The three parameters of the model (P, R, and $\gamma$ ) for biogas yields potentials in each treatment were estimated by the Levenberg-Marquardt algorithm in MATLAB curve fitting software (The MathWorks Inc., MATLAB software, Version 7.6.0). The goodness of fit for each model was evaluated by comparing the coefficient of determinations, $\mathrm{R}^{2}$.

\section{RESULTS AND DISCUSSION}

The trends of daily biogas yield for $35^{\circ} \mathrm{C}$ and $45^{\circ} \mathrm{C}$ treatments are shown in figs. 1 and 2. The results show a high rate of biogas production during the first three days of the experiments. This high rate was due to reaction between the sodium bicarbonate and the acid medium generated by $\mathrm{DRB}$, which caused a rapid generation of $\mathrm{CO}_{2}$. Once this initial reaction was complete, the biogas yield sharply decreased. The normal biogas production started from the fifth day of the process with a gradual increase up to about 10-12 days. Then the daily production gradually decreased. A comparison between the trends of biogas production for $35^{\circ} \mathrm{C}$ and $45^{\circ} \mathrm{C}$ treatments indicates that the treatments with higher temperature and also the treatments with higher percentage of CM yielded a higher amount of daily biogas production.

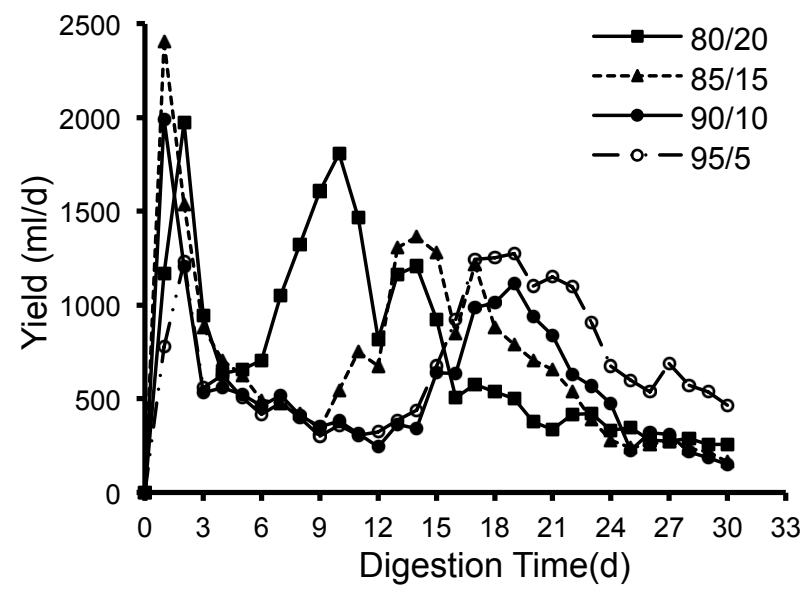

Fig. 2. Daily biogas production for treatments performed at $45^{\circ} \mathrm{C}$. 
Table 3. Characteristics of the organic materials recovered from digestion process after 30 days of hydraulic retention time.

\begin{tabular}{cccccc}
\hline Treatment & $\begin{array}{c}\text { Digestion } \\
\text { Temperature } \\
\left({ }^{\circ} \mathrm{C}\right)\end{array}$ & $\begin{array}{c}\text { Cumulative biogas } \\
\text { Production } \\
(\mathrm{L})\end{array}$ & $\begin{array}{c}\text { Methane } \\
\text { Content } \\
(\%)^{*}\end{array}$ & $\begin{array}{c}\text { VS } \\
(\% \text { of TS })\end{array}$ & $\begin{array}{c}\text { Reduction of VS } \\
(\%)\end{array}$ \\
\hline $80 / 20$ & 35 & $20.2 \pm 0.95(\mathrm{c})$ & $59.4 \pm 7.3$ & 21.5 & 76.2 \\
$85 / 15$ & 35 & $17.8 \pm 0.33(\mathrm{~d})$ & $55.0 \pm 8.8$ & 25.8 & 71.8 \\
$90 / 10$ & 35 & $17.1 \pm 0.18(\mathrm{~d})$ & $50.9 \pm 10.9$ & 28.1 & 69.6 \\
$95 / 5$ & 35 & $15.6 \pm 1.95(\mathrm{e})$ & $48.9 \pm 5.9$ & 32.8 & 64.9 \\
$80 / 20$ & 45 & $23.2 \pm 1.30(\mathrm{a})$ & $60.2 \pm 12.4$ & 16.9 & 81.4 \\
$85 / 15$ & 45 & $21.5 \pm 1.06(\mathrm{~b})$ & $56.1 \pm 16.6$ & 19.6 & 78.5 \\
$90 / 10$ & 45 & $17.4 \pm 0.61(\mathrm{~d})$ & $48.2 \pm 15.7$ & 27.1 & 70.7 \\
$95 / 5$ & 45 & $20.8 \pm 0.33(\mathrm{bc})$ & $49.2 \pm 15.2$ & 21.6 & 76.9
\end{tabular}

\footnotetext{
* All values are expressed as means \pm standard deviation. Letters in parentheses indicate significantly different $(\alpha=0.01)$; TS: total solids, VS: volatile solids.
}

The general trends of biogas production for all treatments were very similar. Characteristics of the organic materials recovered from digestion process after 30 days of HRT are shown in Table 3.

The ANOVA test on the amount of biogas production at different levels of cattle manure after 30 days of HRT indicated that biogas production was significantly increased with increasing the amount of cattle manure in the digesters medium. The total biogas production was significantly higher in treatments with $20 \%, 15 \%$, and $5 \%$ whereas no difference was observed in treatment with $10 \% \mathrm{CM}$. The VS reductions were significantly decreased with increasing the ratio of DRB in the digesters. The high amount of DRB that remained in the digester medium is generally attributed to low temperature of a digestion process. The ANOVA test also indicated that the interaction between temperature and $\mathrm{CM}$ was significant.

Analysis of methane content of daily biogas yield indicated that in general, the percentage of methane in the produced biogas increased up to a peak value of approximately $70 \%$ and then it gradually decreased to

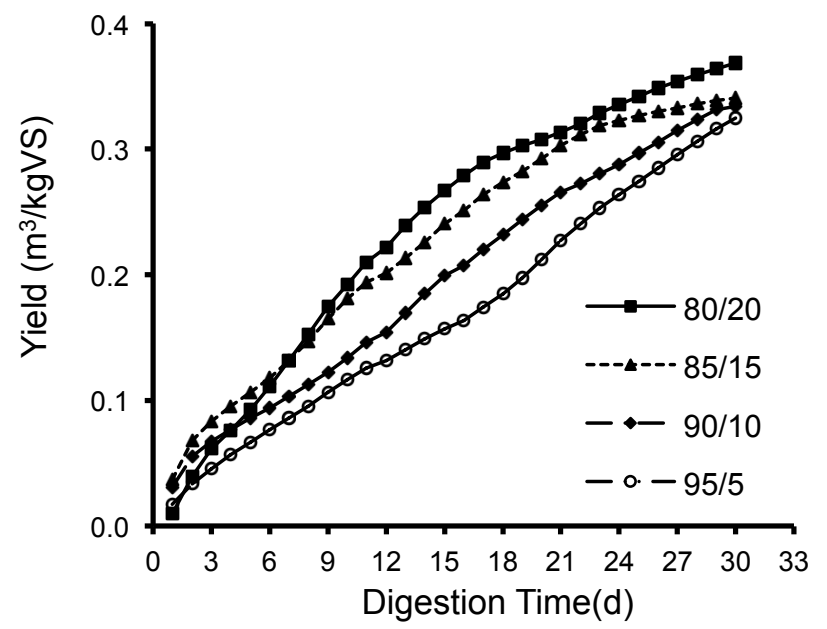

Fig. 3. Cumulative biogas yield for treatments performed at $35^{\circ} \mathrm{C}$. about 55-65\%. However, the peak value occurred at different times for different treatments. The treatments with higher proportion of manure reached their peak value at about 12 days of HRT while the low manure treatments reached their peak value after about 21 days. The maximum peak value, $72 \%$, occurred for $80 / 20$ treatments performed at $45^{\circ} \mathrm{C}$, indicating more methane was generated with increase in digestion temperature. The final methane content of biogas yield after 30 days HRT ranged from 48.9 to $59.4 \%$ for $35^{\circ} \mathrm{C}$ treatments, and from 48.2 to $60.2 \%$ for $45^{\circ} \mathrm{C}$ treatments. The VS reductions in the various treatments, after 30 days anaerobic digestion ranged from 64.9 to $81.4 \%$ that indicates a high conversion of biomass to biogas. The cumulative gas productions for different treatments are presented in figs. 3 and 4.

In general, biogas production was initiated about $24-$ $48 \mathrm{~h}$ (lag time) after the start of the experiments. The production rate continued to increase for 27 days then it gradually decreased. In general, the figures indicate that the lower temperature digesters and the digesters with lower proportion of CM had a larger delay (lag time) in biogas

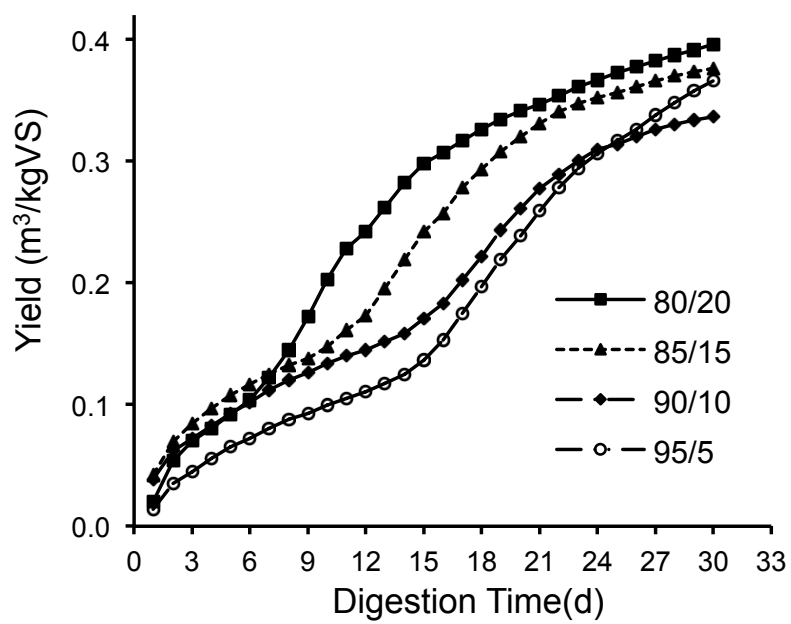

Fig. 4. Cumulative biogas yield for treatments performed at $45^{\circ} \mathrm{C}$. 
Table 4. The estimated parameters of modified Gompertz model and their $\mathbf{R}^{2}$ values for cumulative biogas yields.

\begin{tabular}{|c|c|c|c|c|c|c|}
\hline \multirow{2}{*}{ Treatments } & \multirow{2}{*}{$\begin{array}{c}\text { Digestion } \\
\text { Temperature } \\
\left({ }^{\circ} \mathrm{C}\right)\end{array}$} & \multirow{2}{*}{$\begin{array}{l}\text { Cumulative biogas yield } \\
\qquad\left(\mathrm{m}^{3} / \mathrm{kg} \mathrm{VS}\right)\end{array}$} & \multicolumn{3}{|c|}{ Estimated Gompertz parameters } & \multirow{2}{*}{$\mathrm{R}^{2}$} \\
\hline & & & $\begin{array}{c}P \\
\left(\mathrm{~m}^{3} / \mathrm{kg} \text { VS }\right)\end{array}$ & $\begin{array}{c}R_{m} \\
\left(\mathrm{~m}^{3} / \mathrm{kg} \text { VS.d }\right) \\
\end{array}$ & $\begin{array}{c}\gamma \\
\text { (day) }\end{array}$ & \\
\hline $80 / 20$ & 35 & 0.369 & 0.362 & 0.022 & 1.71 & 0.99 \\
\hline $85 / 15$ & 35 & 0.341 & 0.353 & 0.019 & 1.81 & 0.99 \\
\hline $90 / 10$ & 35 & 0.334 & 0.356 & 0.016 & 2.02 & 0.97 \\
\hline $95 / 5$ & 35 & 0.325 & 0.345 & 0.013 & 2.31 & 0.97 \\
\hline $80 / 20$ & 45 & 0.396 & 0.401 & 0.023 & 1.62 & 0.99 \\
\hline $85 / 15$ & 45 & 0.376 & 0.380 & 0.020 & 1.85 & 0.96 \\
\hline $90 / 10$ & 45 & 0.338 & 0.363 & 0.016 & 2.02 & 0.95 \\
\hline $95 / 5$ & 45 & 0.366 & 0.375 & 0.015 & 2.17 & 0.95 \\
\hline
\end{tabular}

production, a lower potential biogas yield, and slower biogas production rates. The maximum cumulative biogas yields were 0.427 and $0.369 \mathrm{~m}^{3} / \mathrm{kgVS}$ that occurred in the $80 / 20$ treatment at $45^{\circ} \mathrm{C}$ and $80 / 20$ treatment at $35^{\circ} \mathrm{C}$, respectively. The obtained biogas yields for all treatments are higher than those reported for many other agricultural wastes (Isci and Demirer 2007; Satyanarayan et al. 2008). This is likely due to the exposure of DRB to high temperatures during the distillation process.

The results of fitting the Gompertz model to the cumulative biogas production are presented in Table 3 . The Gompertz model predicted the experimental data with a high level of accuracy $\left(R^{2}>0.95\right)$. The estimated parameters for the models, listed in Table 4, indicate that the potential biogas yield parameter, $\mathrm{P}$, and the rate of biogas production, $R_{m}$, both increased with increase of temperature and/or the percentage of CM. But the lag time parameter, $\gamma$, decreased with increase in temperature and $\mathrm{CM}$ percentage. In general, the estimated lag times ranged from a minimum of 1.62 day for $80 / 20$ treatment with $45^{\circ} \mathrm{C}$ digestion temperature to a maximum of 2.31 days for $95 / 5$ treatments performed at the same temperature.

\section{CONCLUSIONS}

The potential of DRB supplemented with cow manure for biogas production was investigated and the overall results indicated that this material has a high potential for biogas production. The DRB digested at $45^{\circ} \mathrm{C}$ and with higher amount of CM yielded a higher amount of biogas. More than $80 \%$ of the total biogas yield was achieved during the first 15 days of digestion process. Maximum cumulative biogas yields were 0.427 and $0.369 \mathrm{~m}^{3} / \mathrm{kgVS}$ for treatments with $20 \% \mathrm{CM}$ at $45^{\circ} \mathrm{C}$ and $35^{\circ} \mathrm{C}$, respectively. The VS reductions in the various treatments, after 30 days of anaerobic digestion ranged from 64.9 to $81.4 \%$. In general, biogas generation increases with increase in both temperature and CM proportion and these two factors had significant interaction effects on biogas production. The daily cumulative biogas yields were fitted to a modified Gompertz equation, resulting with $\mathrm{R}^{2}$ values greater than 0.95 .

\section{ACKNOWLEDGEMENT}

The authors acknowledge the financial support of Zahra Rosewater Co. of Kerman, Iran for this project.

\section{REFERENCES}

Angelidaki, I. and B.K. Ahring. 1994. Anaerobic thermophilic digestion of manure at different ammonia loads: Effect of temperature. Water Research 28 (3): 727-731.

APHA. 1998. Standard Methods for the Examination of Water and Wastewater (20th edition). Washington, DC: American Public Health Association.

Chae, K.J., A. Jang, S.K. Yim and I.S. Kim. 2008. The effect of digestion temperature and temperature shock on biogas yield from the mesophilic anaerobic digestion of swine manure. Bioresource Technology 99(1): 1-6.

Dellepiane, D., B. Bosio and E. Arato. 2003. Clean energy from sugarcane waste: feasibility study of an innovative application of bagasse and barbojo. Journal of Power Sources 122 (1): 47-56.

Doaguei, A.R., 2009. Kinetic evaluation of biogas production from Damask rose bagasse. Unpublished MS thesis. Kerman, Iran: Department of Mechanic of Agricultural Machineries, Shahid Bahonar University.

El Shinnawi, M.M., B.S. El Tahawi, M. El Houssieni and S.S. Fahmy. 1989. Changes of organic constituents of crop residues and poultry wastes during fermentation for biogas production. MIRCEN Journal of Applied Microbiology and Biotechnology 5: 475-486.

Garba, B., 1996. Effect of temperature and retention period on biogas production from lignocellulosic material. Renewable Energy 9: 938-941.

Gomec, Y.C. and R.E. Speece. 2003. The role of $\mathrm{pH}$ in the organic material solubilization of domestic sludge in anaerobic digestion. Water Science and Technology 48(3): 143-150. 
Hashimoto, A.G., V.H. Varel and Y.R. Chen. 1981. Ultimate methane yield from beef cattle waste: effects of temperature, reaction constituents, antibiotics and manure. Agricultural Wastes 3(4): 241-256.

Hansen, K.H., I. Angelidaki and B.K. Ahring. 1998. Anaerobic digestion of swine manure: Inhibition by ammonia. Water Research 32(1): 5-12.

Hansen, K.H., I. Angelidaki and B.K. Ahring. 1999. Improving thermophilic anaerobic digestion of swine manure. Water Research 33(8): 1805-1810.

Isci, A. and G.N. Demirer. 2007. Biogas production potential from cotton wastes. Renewable Energy 32(5): 750-757.

Jain, S.R. and B. Mattiasson. 1998. Acclimatization of methanogenic consortia for low $\mathrm{pH}$ biomethanation process. Biotechnology Letters 20(8): 771-775.

Jalali-Heravi, M., H. Parastar and H. Sereshti. 2008. Development of a method for analysis of Iranian damask rose oil: Combination of gas chromatography mass spectrometry with Chemometric techniques. Analytica Chimica Acta 623(1): 11 - 21.

Koppar, A. and P. Pullammanappallil. 2008. Single-stage, batch, leach-bed, thermophilic anaerobic digestion of spent sugar beet pulp. Bioresource Technology 99(8): 2831 - 2839.

Lay, J., Y. Li and T. Noike. 1997. Influences of $\mathrm{pH}$ and moisture content on the methane production in highsolids sludge digestion. Water Research 31(6): 1518 1524.

Macias-Corral, M., Z. Samani, A. Hanson, G. Smith, P. Funk, H. Yu and J. Longworth. 2008. Anaerobic digestion of municipal waste and agricultural waste and the effect of co-digestion with dairy cow manure. Bioresource Technology 99(17): 8288-8293.
Mu, Y., G. Wang and H. Yu. 2006. Kinetic modeling of batch hydrogen production process by mixed anaerobic cultures. Bioresource Technology 97(11): 1302-1307.

Rajasekaran, P., K.R. Swaminathan and M. Jayapragasam. 1989. Biogas production potential of Euphorbia tirucalli L. along with cattle manure. Biological Wastes 30(1): 75-77.

Satyanarayan, S., P. Murkute and Ramakant. 2008. Biogas production enhancement by Brassica compestries amendment in cattle dung digesters. Biomass and Bioenergy 32(3): 210-215.

Somayaji, D. and S. Khanna. 1994. Biomethanation of rice and wheat straw. World Journal of Microbiology and Biotechnology 10(5): 521-523.

Yadvika, S, T.R. Sreekrishnan, S. Kohli and V. Rana. 2004. Enhancement of biogas production from solid substrates using different techniques - a review. Bioresource Technology 95(1): 1-10.

Zandersons, J., J. Gravitis, A. Kokorevics, A. Zhurinsh, O. Bikovens, A. Tardenaka and B. Spince. 1999. Studies of the Brazilian sugarcane bagasse carbonisation process and product properties. Biomass and Bioenergy 17(3): 209 - 219.

Zennaki, B.Z., A. Zadi, H. Lamini, M. Aubinear and M. Boulif. 1996. Methane fermentation of cattle manure: effects of hydraulic retention time, temperature and substrate concentration. Tropicultural 14(4): 134-140. 